\title{
Report on the $16^{\text {th }}$ International Symposium on Geo-disaster Reduction, 27-31th August 2018, Strasburg, France
}

\author{
Xiaoli Su', Miguel Clüsener-Godt ${ }^{2}$ and Fawu Wang ${ }^{3 *}$
}

\begin{abstract}
On 27-31th August 2018, the 16th International Symposium on Geo-disaster Reduction (ISGdR) has been held in Strasburg, France, focusing on the theme of "Global Strategy for Geo-disaster Reduction". Through Keynote Lectures, Scientific Session, Poster Session and Field Excursion, this symposium has successfully provided an international platform for scholars, scientists, industrial professionals, practitioners and students to discuss interdisciplinary research and practices in the fields of the reduction of the disasters triggered by geological and geophysical phenomena on the earth.
\end{abstract}

\section{Organizers and organizing committee}

This symposium has been jointly organized by University of Strasbourg, France, the International Consortium on Geo-disaster Reduction (ICGdR) and the UNESCO Chair on Geo-environmental Disaster Reduction in Shimane University, Japan.

The major Organizing Committee members of this symposium includes: Patrick Wassmer (University of Strasbourg, France), Fawu Wang (ICGdR Director-General), and Masakatsu Miyajima (ICGdR President).

\section{Report of the 16th ICGdR}

The 16th International Symposium on Geo-Disaster Reduction (ISGdR) has been focusing on the theme of "Global Strategy for Geo-disaster Reduction" and attracted more than 60 scientists and engineers from Japan, France, China, Italy, Morocco, United Kingdom, Czech Republic, Indonesia and Belgium etc. to give 55 high-quality academic presentations in the field of geo-disasters. There were three major sessions in this symposium: Keynote Lectures, Scientific Session and Poster Session, offering an opportunity to discuss the most recent advances in the field of Geo-Disaster Reduction. In addition to the main sessions of the symposium, pre-event and post-event have also been organized.

\footnotetext{
* Correspondence: wangfw@riko.shimane-u.ac.jp

${ }^{3}$ Department of Earth Science, Shimane University, Matsue 690-8504,

Shimane, Japan

Full list of author information is available at the end of the article
}

\section{Pre-event}

On 27th August 2018, the annual council meeting of ICGdR was held in the UNESCO headquarter, Paris. Dr. Miguel Clüsener-Godt, the Director of Division of Ecological and Earth Sciences, UNESCO delivered a welcome speech. He said:

Dear Excellences, Ladies and Gentlemen, Distinguished guests,

It gives me great pleasure to address you all at this Annual Council Meeting of the International Consortium on Geo-disaster Reduction (ICGdR).

I greet all ICGdR members, with particular recognition of Professor Miyajima Masakatsu, President of the ICGdR for hosting this event here at UNESCO for the first time. I would also like to thank Prof. Fawu Wang, Director-General of ICGdR for organizing this meeting.

Let me recall that the relationship between ICGdR and UNESCO started when ICGdR together with Shimane University established UNESCO chair as a centre of excellence focusing on the nexus of the Geoenvironmental Disaster Reduction Improving the Relationship between Geoenvironment and Society in 2017. UNESCO participated the ICGdR annual meeting (15ISGdR) last August 2017 in Shimane, Japan to discuss about the issues on geohazards risk and prevention measures. Later, Flavia Schlegel, our Assistant-Director General for Natural Sciences visited Shimane University for the celebration event of newly approved UNESCO Chair on Geoenvironmental 


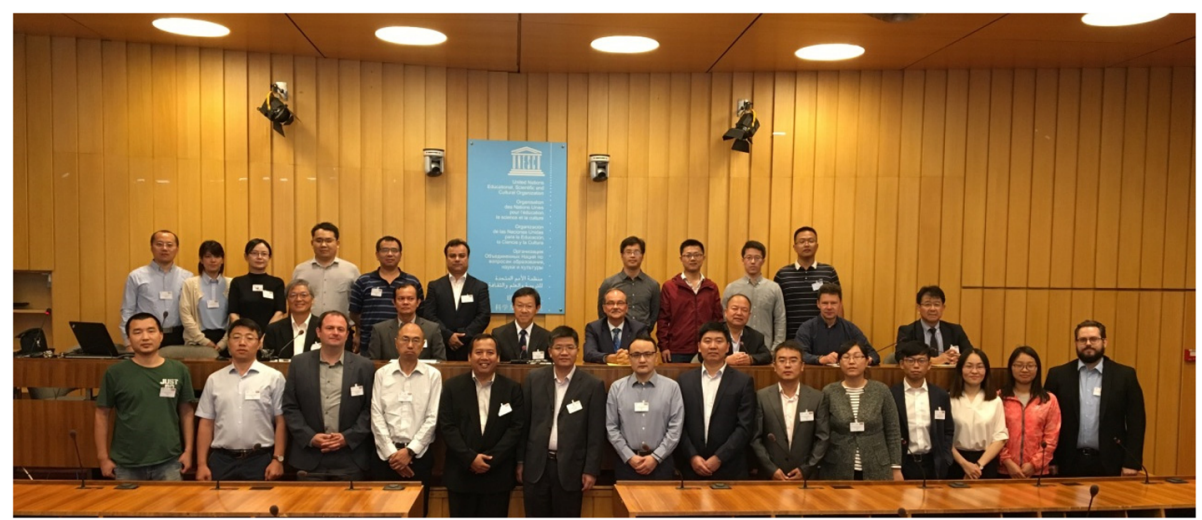

Fig. 1 Group photo at the annual meeting

Disaster Reduction in November 2017. She is very satisfied with the active engagement of Shimane University and ICGdR on the geohazard disaster risk reduction. She was also impressed with the local community living with the geo-sites in Oki UNESCO Global Geopark, where she visited during her stay in Shimane.

The 2030 Agenda, adopted in 2015 by the United Nations, represents a significant step forward in terms of recognizing science, technology and innovation (STI) as a driving force for sustainable development in its three pillars, environmental, social and economic. As the only UN agency that includes science in its mandate, UNESCO finds itself at the heart of this initiative. It implements its activities through its global network of field offices, international scientific programmes, centres, institutes, and the UNESCO Chairs and UNITWIN Networks.
The UNITWIN/UNESCO Chairs Programme celebrated its 25th anniversary in 2017. Today, there are more than 700 UNESCO Chairs and UNITWIN Networks around the world, and more than 170 of these specialise in the fields covered by the Natural Sciences Sector of UNESCO. They provide a unique scientific expertise in the United Nations context and significant global, regional and local impacts, in a wide array of relevant fields. The UNESCO Chairs and UNITWIN Networks in Natural Sciences have an important role to play in the shared efforts to link science, policy and society through adopting open science practices to implement the 2030 Agenda for Sustainable Development and other United Nations development agendas.

Disasters induced by natural hazards affect millions of people every year worldwide. The resulting loss of life is tragic, highlighting the vulnerabilities

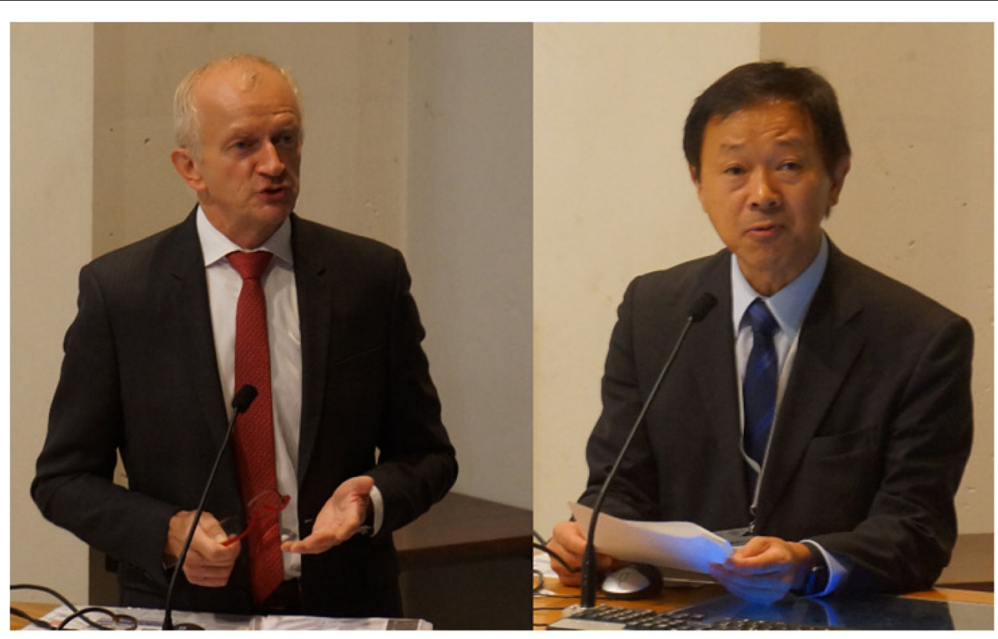

(a)

(b)

Fig. 2 Opening speech presented by a Prof. Michel Deneken b Prof. Masakatsu Miyajima 


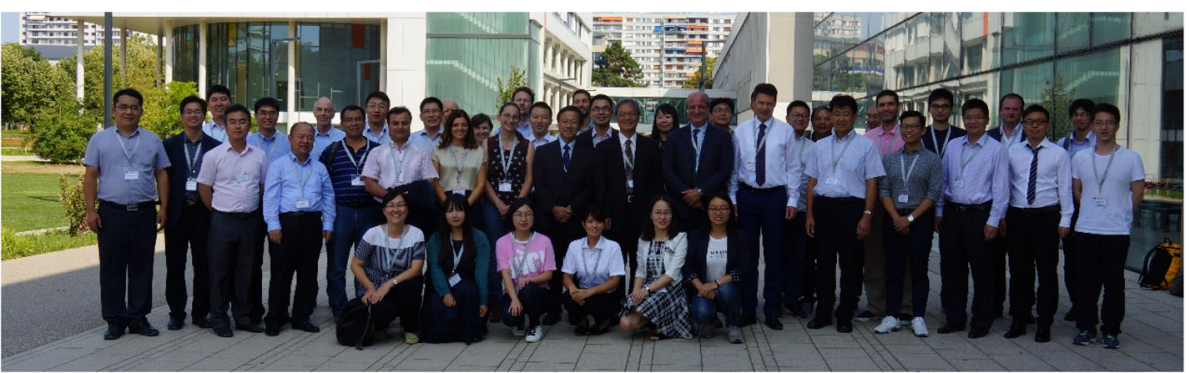

Fig. 3 Group photo of participants of the 16th ICGdR

all societies share. Just to name a few in the last few months, we are witnessing devastating natural hazards around the globe. The State of Kerala in India is suffering from the worst flooding since 1924 caused by cumulative rainfall and more than 200,000 people needed to evacuate. At least 5 large scale earthquakes repeatedly hit the Island of Lombok in Indonesia in July and August. Successive torrential rain in June and July in western Japan caused devastating flood and mudflow and more than 200 people died. The impact is also economical, with disasters leading to estimated annual economic losses of USD\$ 250 to 300 billion - these losses will increase with the rising pressures of climate change, overpopulation and urbanization.

I would like to share with you how UNESCO seriously works with UNESCO Chairs.

The UNESCO Chairs and UNITWIN Networks linked to the Natural Sciences Sector gathered for the first time in Geneva from 5 to 7 July 2017 for the Conference "Mobilizing UNESCO Chairs in Natural Sciences for Policy Action Towards the 2030 Agenda". The results of the deliberations and reflections about how UNESCO Chairs can contribute to the achievement of the 2030 Agenda are expressed in form of the Geneva Milestone.

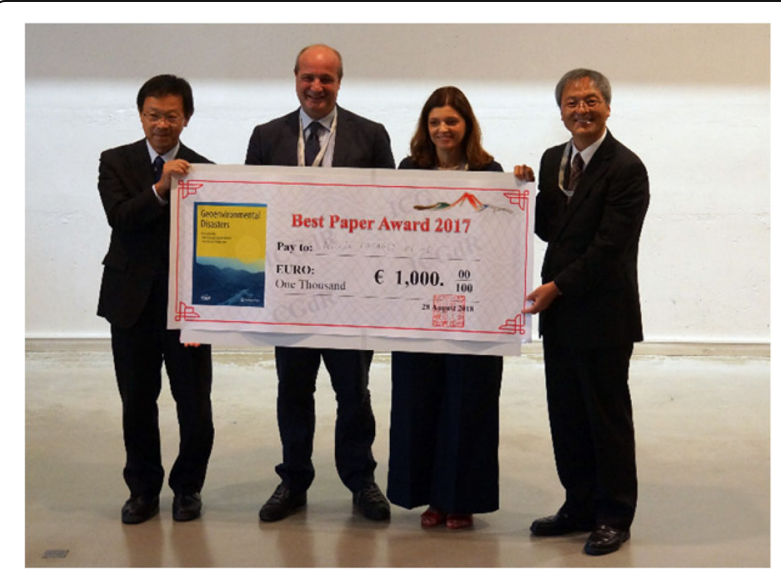

Fig. 4 The winner of the 2017 Best Paper Award of the journal Geo-environmental Disasters
The Geneva Milestone contributes to guiding the future endeavours of the UNESCO Chairs in Natural Sciences in close cooperation with the UNESCO family and the UNESCO National Commissions, as a blueprint for potential activities and cooperation avenues, throughout the following concrete areas;

- Uphold the values of UNESCO, and incorporate those of the 2030 Agenda for Sustainable Development, into the operations of UNESCO Chairs, at organizational level and in their research, teaching and outreach.

- Increase and enhance the focus of UNESCO Chairs and UNITWIN Networks activities on the2030 Agenda.

- Foster interdisciplinarity and transdisciplinarity throughout UNESCO Chairs and UNITWIN Networks, crucial for the successful implementation of the SDGs.

- Influence the host academic institutions by UNESCO Chairs towards putting societal interests and policy makers and the 2030 Agenda at the core of their mission.

- Engage in concrete impact-driven actions to strengthen Chairs and Networks exchanges, particularly through regional, inter-regional,

Table 1 Lists of the presentation in Keynote Lectures

\begin{tabular}{llll}
\hline No. & Title & Presenter & Affiliation \\
\hline K-1 & $\begin{array}{l}\text { European and Mediterranean } \\
\text { major hazards agreement } \\
\text { of the Council of Europe } \\
\text { (EUR-OPA) }\end{array}$ & $\begin{array}{l}\text { Gianluca } \\
\text { Silvestrini }\end{array}$ & $\begin{array}{l}\text { EUR-OPA Executive } \\
\text { Secretary }\end{array}$ \\
K-2 & $\begin{array}{l}\text { Recent landslides triggered } \\
\text { by moderate earthquakes } \\
\text { in Japan }\end{array}$ & Fawu Wang & \\
K-3 $\begin{array}{l}\text { Sentinel-1 continuous } \\
\text { streaming for landslide } \\
\text { monitoring and mapping }\end{array}$ & Nicola & Japan \\
K-4 $\begin{array}{l}\text { In 27 years, lahars have } \\
\text { reached some maturity } \\
\text { at Mt. Unzen Fugendake: } \\
\text { geophysical and } \\
\text { geomorphometric } \\
\text { evidences }\end{array}$ & Gomez & Italy \\
\hline
\end{tabular}




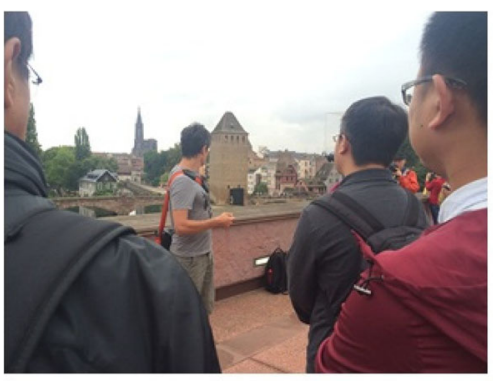

(a)

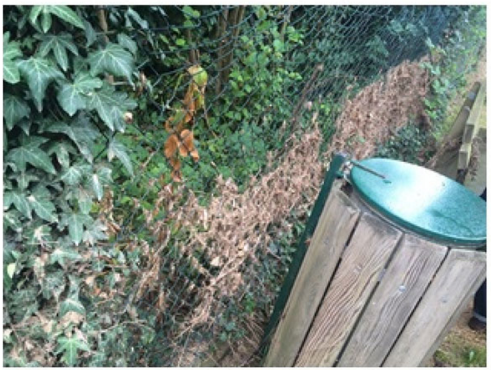

(c)

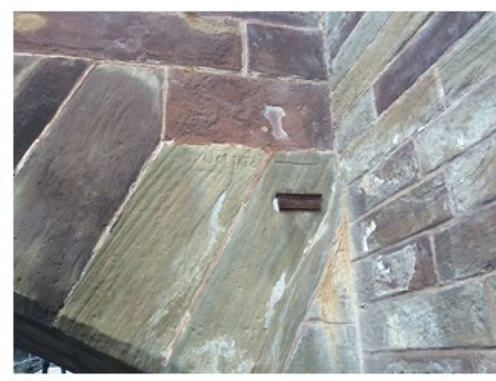

(b)

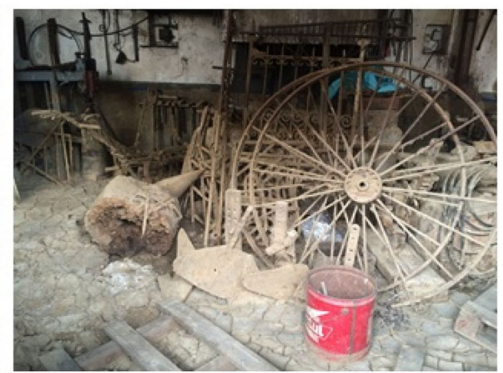

(d)

Fig. 5 Photos at the field excursion. a Introduction to the flooding prevention measures in Strasburg; $\mathbf{b}$ The historical flooding level at the bridge: c The trace left by flooding on the fence in the village near Strasburg in May; $\mathbf{d}$ The house after being flooded by water

South-South, and South-South-North cooperation, in order to enhance their capabilities and improve their leading role within their fields.

- Promote the establishment of networks and working groups of Chairs, at national, regional or thematic levels, to enhance communication, create linkages and support programme development.

UNESCO is committed to playing an active role to develop and strengthen collaboration with you for disaster resilience. We are ready to cooperate with you. We would also like to address that UNESCO is an advisor of International Consortium on Geo-disaster Reduction.

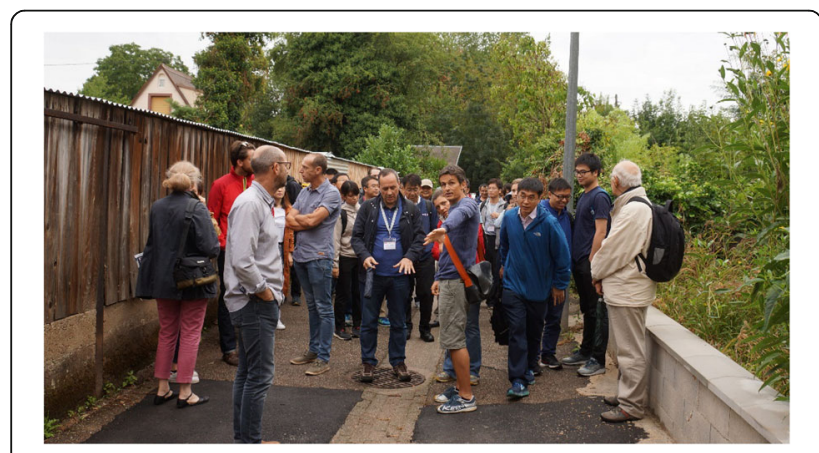

Fig. 6 Finding the mudflow direction in the field excursion
Thank you very much again for your strong engagement for disaster risk reduction. I wish you a fruitful discussion today.

After that, the president of ICGdR Masakatsu Miyajima delivered the opening speech, and the Director-General of ICGdR, Fawu Wang reported the financial situation of ICGdR and the work plan for next year, as well as the sustainable development of the ICGdR official journal: Geoenvironmental Disaster. In the following, the organizing committee selected the advanced individual and advanced group, and also set up the committee of slope toughness and bearing capacity based on anti-seismic performance design. At the end of meeting, it is announced that the 17th ICGdR would be held on 26-30th August 2019 in Kyrgyzstan. A group photo of representatives to the meeting has been taken in the UNESCO headquarter (Fig. 1).

\section{Plenary sessions of the symposium 16ISGdR}

\section{Opening ceremony}

Prof. Fawu Wang, the Director-General of ICGdR facilitated the opening ceremony. Two speeches were presented as the prelude (see Fig. 2). At the beginning, Prof. Michel Deneken, the president of Strasburg University, France, declared the conference to open on behalf of the organizers, and also delivered an opening speech to welcome all the distinguished scholars and experts from all over the world. In the following, Prof. Masakatsu Miyajima, the president of ICGdR 
welcomed all the researchers and expressed his gratitude to the organizers, reported the work of ICGdR council and committee for the last year. The opening ceremony ended up with a group photo as shown in Fig. 3.

\section{Certificate and award ceremony}

In the certificate and award ceremony, Prof. Ma Masakatsu Miyajima presented the 2018 ICGdR Award for Fundamental Research to Fawu Wang (Shimane University, Japan) and Tonglu Li ((Chang'an University, China), presented the 2018 ICGdR Award for Application Research to Mingjian $\mathrm{Hu}$ (State Key Laboratory of Geomechanics and Geotechnical Engineering, Institute of Rock and Soil Mechanics, Chinese Academy of Sciences) and Jianhui Long (Taiyuan University of Technology, China). Besides that, the 2018 ICGdR Best Activity Award was given to Netra Prakash BHANDARY (Ehime University, Japan) and Center for Natural Disaster Reduction Research and Education, Shimane University, Japan. The 2017 Best Paper Award of the ICGdR official journal: Geoenvironmental Disasters was awarded to the paper entitled "Spaceborne, UAV and ground-based remote sensing techniques for landslide mapping, monitoring and early warning" by Nicola Casagli, William Frodella, Stefano Morelli, Veronica Tofani, Andrea Ciampalini, Emanuele Intrieri, Federico Raspini, Guglielmo Rossi, Luca Tanteri and Ping Lu in No. 9, Vol. 4. A cheque worth of one thousand Euro was awarded to the authors' representatives (Fig. 4).

\section{Keynote lectures}

The keynote lectures included 4 presentations as summarized in Table 1. This section was chaired by Prof. Vit Vilimek. Prof. Gianluca Silvestrini gave a presentation related to European and Mediterranean Major Hazards Agreement of the Council of Europe (EUR-OPA). Prof. Fawu Wang presented his research on recent landslides triggered due to moderate earthquake in Japan. Prof. Nicola Casagli gave a speech about sentinel-1 continuous streaming for landslide monitoring and mapping. Prof. Christopher Gomez introduced his research on lahars generated in the Unzen Volcano eruption.

\section{Parallel sessions}

The parallel sessions included Scientific Session and Poster Session. There were 55 presentations from 9 countries on the topics of earthquakes and Tsunamis, physical modeling of mass movements, physical properties and stability of soil, risk and society, and countermeasures.

\section{Post-event}

On 30th August 2018, a field excursion on flooding risk in Rhine River Graben has been organized (Fig. 5). During the excursion, the participants visited the dam for flood prevention, water-gate system for flood regulation, and the bridge on which the scale lines of historical flood exist. There remains evidence that the mudflow carrying with suspended sediment flowed over the fence in a village where a mudflow disaster just occurred in May this year. Some experts guided participants to identify mudflow direction according to the straw left on the fence after the event (Fig. 6).

\section{Invitation}

The 17th ISGdR will be held on 18-24th August 2019 in Kyrgyzstan. The ICGdR will invite all entities and individuals, who are willing to contribute to the geo-disaster reduction to join the 17 ISGdR.

\section{Authors' contributions \\ XS and MC-G wrote the draft, and FW refined it. All authors read and approved the final manuscript.}

\section{Competing interests}

The authors declare that they have no competing interests.

\section{Publisher's Note}

Springer Nature remains neutral with regard to jurisdictional claims in published maps and institutional affiliations.

\section{Author details}

${ }^{1}$ School of Architecture, Building and Civil Engineering, Loughborough University, Loughborough, UK. ²Division of Ecological and Earth Sciences, UNESCO, Shimane University, Shimane, Japan. ${ }^{3}$ Department of Earth Science, Shimane University, Matsue 690-8504, Shimane, Japan.

Received: 11 October 2018 Accepted: 11 October 2018

Published online: 12 November 2018

\section{Submit your manuscript to a SpringerOpen ${ }^{\circ}$ journal and benefit from:}

- Convenient online submission

- Rigorous peer review

- Open access: articles freely available online

- High visibility within the field

- Retaining the copyright to your article

Submit your next manuscript at $\boldsymbol{\nabla}$ springeropen.com 